\title{
THE EFFECT OF PEER GROUP SOCIAL CAPITAL ON SMOKING BEHAVIOR AMONG ADOLESCENTS IN KULON PROGO, YOGYAKARTA
}

\author{
Sujono Riyadi',5), Suminah²), Muhammad Akhyar3), Bhisma Murti4) \\ 1)Doctoral Program in Health Promotion and Community Development, \\ Universitas Sebelas Maret \\ 2)Faculty of Agriculture, Universitas Sebelas Maret \\ 3)Faculty of Teaching and Educational Sciences, Universitas Sebelas Maret \\ 4) Masters Program in Public Health, Universitas Sebelas Maret \\ 5)Faculty of Health, Universitas Jenderal Achmad Yani, Yogyakarta
}

\begin{abstract}
Background: Almost 5.4 million people die annually from smoking. It is estimated that in 2030, deaths from smoking will reach 8 million per year, $80 \%$ of which will correspond to developing countries. Smokers have about 20-25 years less life expectancy. Smoking is associated with various diseases such as heart and respiratory diseases, stroke and cancer. This study aimed to determine the effect of peer group social capital on smoking behavior among adolescents in Kulon Progo, Yogyakarta.

Subjects and Method: This was a case control study conducted in Kulon Progo, Yogyakarta, from April to June 2018. A total of 400 adolescents consisting of 200 smokers and 200 non smokers were selected for this study. The dependent variable was smoking behavior. The independent variables were intention, subjective norm, and peer group social capital. The data were collected by questionnaire and analyzed by a path analysis.

Results: The decision not to smoke was associated with strong intention $(b=1.74$; $95 \% \mathrm{CI}=2.29$ to $1.18 ; \mathrm{p}<0.001)$, favorable subjective norm $(\mathrm{b}=1.58 ; 95 \% \mathrm{CI}=0.99$ to 2.18 ; $\mathrm{p}<0.001)$, favorable peer group social capital $(\mathrm{b}=2.88 ; 95 \% \mathrm{CI}=1.50$ to $4.46 ; \mathrm{p}=0.038)$

Conclusion: The decision not to smoke is associated with intention, subjective norm, and peer group social capital.
\end{abstract}

Keywords: smoke, intention, subjective norm, social capital, peer group.

\section{Correspondence:}

Sujono Riyadi. Doctoral Program in Health Promotion and Community Development, Universitas Sebelas Maret, Surakarta, Central Java.

Email: sujono_kmpk2005@yahoo.com. Mobile: 08122717637

The 4th International Conference on Public Health

Best Western Premier Hotel, Solo, Indonesia, August 29-30, 2018 | 136 https://doi.org/10.26911/theicph.2018.02.17 